\title{
Observed Soil Moisture-Precipitation Feedback in Illinois: A Systematic Analysis over Different Scales $\mathscr{O}$
}

\author{
H. M. DUERINCK \\ Department of Water Management, Faculty of Civil Engineering and Geosciences, Delft University of Technology, \\ Delft, Netherlands, and Department of Civil and Environmental Engineering, National University \\ of Singapore, Singapore \\ R. J. VAN DER ENT, N. C. VAN DE GIESEN, AND G. SCHOUPS \\ Department of Water Management, Faculty of Civil Engineering and Geosciences, Delft University of Technology, \\ Delft, Netherlands \\ V. BABOVIC AND PAT J.-F. YeH \\ Department of Civil and Environmental Engineering, National University of Singapore, Singapore
}

(Manuscript received 28 February 2015, in final form 3 December 2015)

\begin{abstract}
The lack of understanding on the soil moisture-precipitation feedback mechanisms remains a large source of uncertainty for land-atmosphere coupled models. Previous observation-based studies on the soil moistureprecipitation feedback in Illinois have shown contradictory results. This paper extends earlier research by providing a more holistic analysis considering different scales based on an 11-yr (2003-13) hourly soil moisture dataset, which makes it possible to revisit the disputed hypothesis on the correlation between warmseason soil moisture and subsequent precipitation. This study finds a strong positive correlation between late spring/early summer state-average soil moisture at the root-zone depths and subsequent state-average summer precipitation. On the daily to weekly time scale, however, no relation is found. Moreover, regional analysis suggests that precipitation variability over central Illinois can be best explained by the soil moisture variability in northwest Illinois. Using a back-trajectory method [Water Accounting Model-2 layers (WAM2layers)] from May to July, the evaporative sources of precipitation in Illinois are identified. The pattern of the source regions shows little interannual variability, while the strength of the sources changes significantly and the Gulf of Mexico contributes more during wet years. However, strong influences (teleconnections) of sea surface temperatures on the subsequent precipitation variability in Illinois are not found on a seasonal scale. The long time scale of the soil moisture-precipitation correlation and the weak influences of SSTs and climate indices may suggest that precipitation variability in spring/summer in Illinois is mostly related to continental-scale soil moisture-precipitation feedback.
\end{abstract}

๑ Denotes Open Access content.

Supplemental information related to this paper is available at the Journals Online website: http://dx.doi.org/10.1175/JHM-D-150032.s1.

Corresponding author address: H. M. Duerink, Department of Water Management, Faculty of Civil Engineering and Geosciences, Delft University of Technology, Stevinweg 1, 2628CN Delft, Netherlands.

E-mail: hmduerinck@gmail.com

\section{Introduction}

Soil moisture is a key control for the partitioning of energy at the land-atmosphere interface into latent heat (evaporation) and sensible heat (Koster et al. 2004, 2011; Seneviratne et al. 2010). Wet soils favor more transpiration, of which more than half is expected to return as precipitation to the land surface (WangErlandsson et al. 2014; van der Ent et al. 2014). Besides providing moisture input, soil moisture also influences precipitation indirectly. The impact of soil moisture on the heating and cooling of the near-surface air 
temperatures influences the atmospheric boundary layer (ABL) conditions (e.g., turbulence, wind, convection, cloud cover, downward radiation, and ABL thickness) and thereby the processes of precipitation development (e.g., Findell and Eltahir 2003a; Ek and Holtslag 2004; Santanello et al. 2005; Siqueira et al. 2009; Van Heerwaarden et al. 2009; Konings et al. 2010; Stéfanon et al. 2014). Both the direct and indirect influences of soil moisture on precipitation are captured in the concept of soil moisture-precipitation feedback, which is the twoway coupling between soil moisture and precipitation.

A major challenge in investigating soil moistureprecipitation feedbacks is to determine causal relations (Salvucci et al. 2002). This is largely because such interactions take place in the atmosphere over different temporal and spatial scales, where processes are complex and difficult to observe. Many studies have tried to improve the understanding of soil moisture-precipitation feedbacks by creating a controlled environment using simulation models. However, the lack of process understanding remains a large source of uncertainty for land-atmosphere coupled models in general (e.g., Dirmeyer et al. 2006; Hohenegger et al. 2009; Seneviratne et al.2010). Observational studies show that both positive and negative feedbacks may occur (Findell and Eltahir 2003b; Findell et al. 2011; Taylor et al. 2011, 2012; Guillod et al. 2014).

Illinois has a long history of monitoring of soil moisture at several sites in the Illinois Climate Network. Since 2003, soil moisture has been measured there at an hourly basis. Earlier observational studies did not have access to this wealth of data and based their results on bimonthly data over the period 1981-94 (e.g., Findell and Eltahir 1997; Salvucci et al. 2002). Findell and Eltahir (1997) found a weak but significant positive correlation between late spring/early summer soil saturation and total summer precipitation based on the interpolated low-resolution soil moisture data. They found the precipitation autocorrelation to be lower than the soil moisture-subsequent precipitation correlation. This was considered as supporting evidence of a positive soil moisture-precipitation feedback mechanism. The usefulness of determining the autocorrelation of precipitation, however, is limited, as a strong precipitation persistence says little about the underlying processes. It could be the result of a positive local (i.e., over Illinois) soil moisture precipitation feedback as well as the result of nonlocal confounding factors, such as sea surface temperature (SST) or continental soil moisture (e.g., Guillod et al. 2014).

In contrast to the results of Findell and Eltahir (1997), Salvucci et al. (2002) estimated the same correlations to be half as large based on the same data, without interpolating missing soil moisture values. They argued the correlation found by Findell and Eltahir (1997) to be mainly an artifact, because the interpolated values were based on future values and therefore being biased positively when correlated with future precipitation. Salvucci et al. (2002) proposed the Granger causality test as a better proxy for determining causality and argued that soil moisture variations do not significantly influence precipitation. However, because of the different methods (simple linear regression vs Granger causality test), precipitation metrics (total precipitation vs precipitation occurrence), and temporal ( 21 days per summer vs 1 day) and spatial (statewide vs point) scales used, the two studies actually evaluated different aspects.

The goal of this study is to systematically revisit the disputed hypothesis of (positive) soil moistureprecipitation feedback. This is done by analyzing the hourly (since 2003) soil moisture and precipitation data of 18 stations in the Illinois Climate Network at different temporal and spatial scales, wherefore the method by Findell and Eltahir (1997) is extended. In addition, this paper aims to provide more insight into the origin of the observed correlations. As precipitation obviously influences soil moisture, positive correlations found between soil moisture and precipitation may be merely a result of experiencing the same synoptic weather patterns driven by SSTs. The simple persistence induced by synoptic weather patterns could lead to spurious correlations at the short to medium time scale.

The long distances from the oceans provide a large area for land-atmosphere interaction to take place. As such, soil moisture can influence large-scale atmospheric circulations (Pal and Eltahir 2002). Moreover, while large-scale atmospheric circulations are associated with the onset of droughts and floods, soil moisture conditions are believed to be able to enhance them and aid in their persistence (Namias 1991; Beljaars et al. 1996; Seth and Giorgi 1998; Bosilovich and Sun 1999; Pal and Eltahir 2001, 2002). Therefore, the evaporative source areas for precipitation are identified, and the same correlation analysis for soil moisture versus precipitation is also performed for local SSTs and climate indices versus precipitation. Finally, it is investigated if soil moisture in certain areas of Illinois can predict precipitation in other areas better than the soil moisture in that area itself.

\section{Study area}

The study area of this research is the state of Illinois (Fig. 1). Illinois is located in U.S. Midwest and borders Lake Michigan. It covers an area of $146075 \mathrm{~km}^{2}$, spanning $620 \mathrm{~km}$ long $\left(36.9540^{\circ}-42.4951^{\circ} \mathrm{N}\right)$ and $351 \mathrm{~km}$ wide 


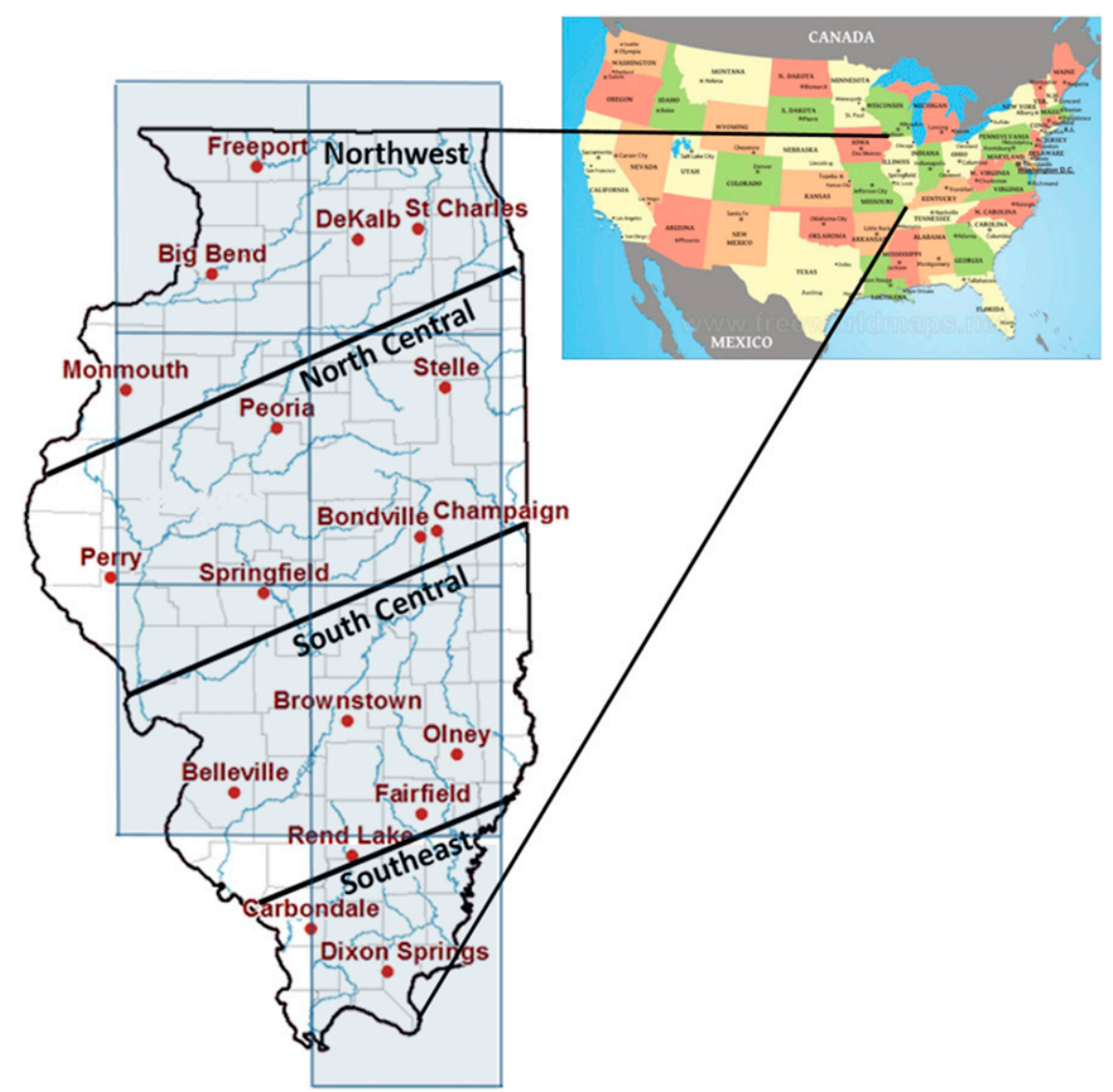

FIG. 1. Study area with the locations of the stations of the Illinois Climate Network and with the demarcations of the four climatological zones and the grid cells of the atmospheric moisture tracking model WAM-2layers that are in Illinois. Adapted from Illinois State Water Survey (2014) and Free World Maps (2014).

$\left(87.3840^{\circ}-91.4244^{\circ} \mathrm{W}\right)$. More than three-quarters of land use is agriculture (mostly corn and soybeans), which is mainly rain fed (Angel 1999). The state is fully located within the Central Plains and is relatively flat, with its highest point being $376.4 \mathrm{~m}$. The state exhibits only a few hill formations, with the extension of the Wisconsin's Driftless Area in the northwest and the fringes of the Ozark Plateau and Shawnee Hills in the southern part (Angel 1999).

Illinois has a typical continental climate with cold winters and warm summers. Average temperature ranges from $-1.7^{\circ} \mathrm{C}$ in winter to $24.1^{\circ} \mathrm{C}$ in summer, with January being the coldest month and July the hottest. There is a temperature gradient with overall lower temperatures in the north and higher in the south, except for summer, when temperatures are about the same (Angel 2009). The prevailing wind direction varies across Illinois with frequent short fluctuations. During summer months, the prevailing wind direction is south to southwest. During the rest of the year, the direction is less clear (Wendland 1981; Angel 2009). Precipitation and soil moisture conditions in Illinois are discussed in section 3 .

\section{Data}

The precipitation and soil moisture datasets used in this analysis are obtained from the Illinois State Water Survey for the period 2003-13 (Water and Atmospheric Resources Monitoring Program 2011). The minimum for studying land-atmosphere interactions is 11 years (Findell et al. 2015). The data are collected by the 18 stations of the Illinois Climate Network (Fig. 1). The stations are located in an open and sod-covered area. Soil moisture is measured at six depths $(5,10,20,50$, 100 , and $150 \mathrm{~cm}$ ) using a Stevens HydraProbe sensor. Precipitation measurements were obtained by a Belfort universal precipitation gauge prior to summer/fall 2008 and afterward using an OTT Pluvio precipitation gauge. 


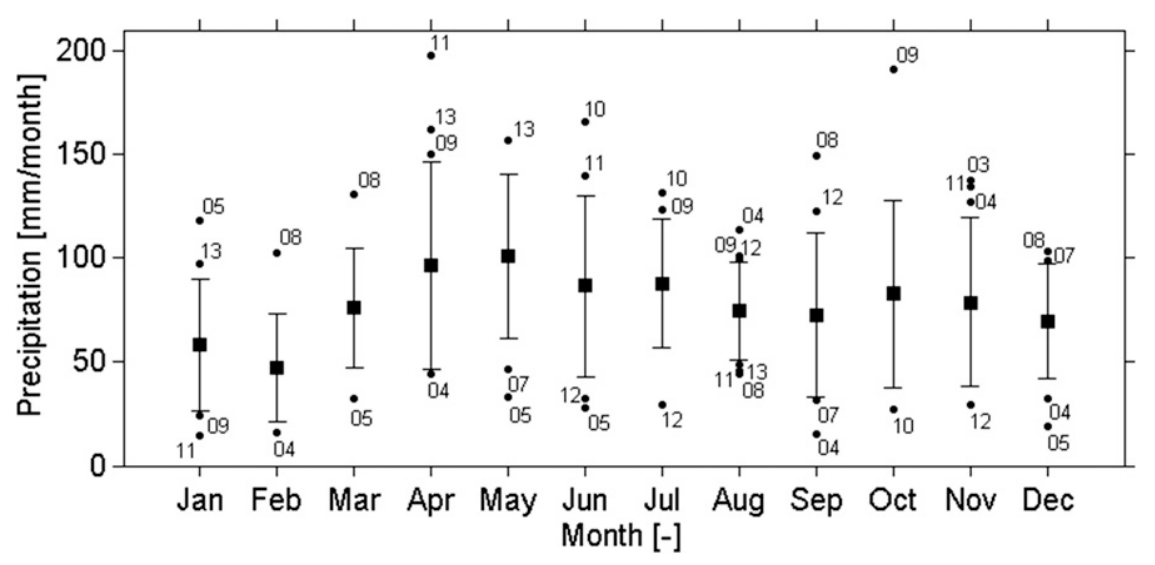

FIG. 2. The statewide mean of total monthly precipitation for the period 2003-13 (squares). The lines extend to plus or minus one std dev. The numbered dots indicate years that deviate more than one std dev from the mean.

\section{a. Precipitation}

Figure 2 presents the statewide mean of monthly precipitation for the period 2003-13 with their corresponding standard deviations and years with anomalous precipitation (outside the standard deviation range). Monthly precipitation is highest during spring with a maximum of about $100 \mathrm{~mm} \mathrm{month}^{-1}$ being reached in May. From April to July, the years 2005 and 2012 return most often as anomalously dry and the years 2009, 2010, and 2013 as anomalously wet. Geographically, there is a precipitation gradient with the lowest amount falling in the northwest $(850 \mathrm{~mm})$ and the highest amount in the southeast $(1200 \mathrm{~mm})$. Based on this gradient, four climatological zones (northwest, north-central, southcentral, and southeast) can be distinguished (Fig. 1). The snowfall distribution component of precipitation, however, is the opposite, with averages from $915 \mathrm{~mm} \mathrm{yr}^{-1}$ (snow depth, not to be confused with water equivalent depth) in the north to less than $255 \mathrm{~mm} \mathrm{yr}^{-1}$ in the far south. About $50 \%-60 \%$ of the annual precipitation originates from thunderstorms, which occur most frequently during June-August (nearly $50 \%$ of all thunderstorm days; Angel 1999). More information on the precipitation data can be found in part A of the supplemental material.

\section{b. Soil moisture}

Figure 3 gives an indication of the seasonal variation of soil moisture. The figure presents the spatially averaged soil moisture content $\theta$ (i.e., volumetric water content) at a depth of $50 \mathrm{~cm}$ for the years 2003-13. The years with drier summer conditions are colored red, yellow, and orange (2005, 2007, and 2012) and the years with wet conditions are colored blue $(2009,2010$, and
2013). The years with anomalously dry summers coincide with reported droughts in Illinois (Kunkel et al. 2006; Illinois Department of Natural Resources 2013).

The amount of water in the soil is highest during January-April when soil moisture content reaches values around 0.38 . Over these months, the average monthly evaporation rates, which are almost zero during winter, stay well below the monthly precipitation averages. The major soil texture class in Illinois is silty loam. This class is characterized by a medium to fine granularity associated with a porosity of around 0.5 . Thus, the average soil saturation is around $75 \%$ during these months. This is about the field capacity of silty loam (Rowell 1995), which suggests that percolation occurs in this period. The average watertable depth in Illinois is about $2-3 \mathrm{~m}$ (Yeh and Famiglietti 2009).

From May to August, drying of the soil takes place as soil moisture content decreases on average to about 0.3 , indicating more evaporation and water release than incoming precipitation. In May, the evaporation is about the same as precipitation, and from July to August evaporation exceeds precipitation, reaching average rates of about $100-120 \mathrm{~mm} \mathrm{month}^{-1}$ (Yeh and Famiglietti 2009). Given that evaporation is most prominent during spring and summer, this paper focuses on the period April-August when investigating the soil moistureprecipitation feedback. This is in fact the drying part of the seasonal soil moisture cycle, and interannual variability in soil moisture is strongest during this period. The soil moisture-limited regime during AprilAugust leads to high interannual variability in evaporation (Seneviratne et al. 2010).

The seasonal variation of soil moisture at depths shallower than $50 \mathrm{~cm}$ shows a similar pattern containing 


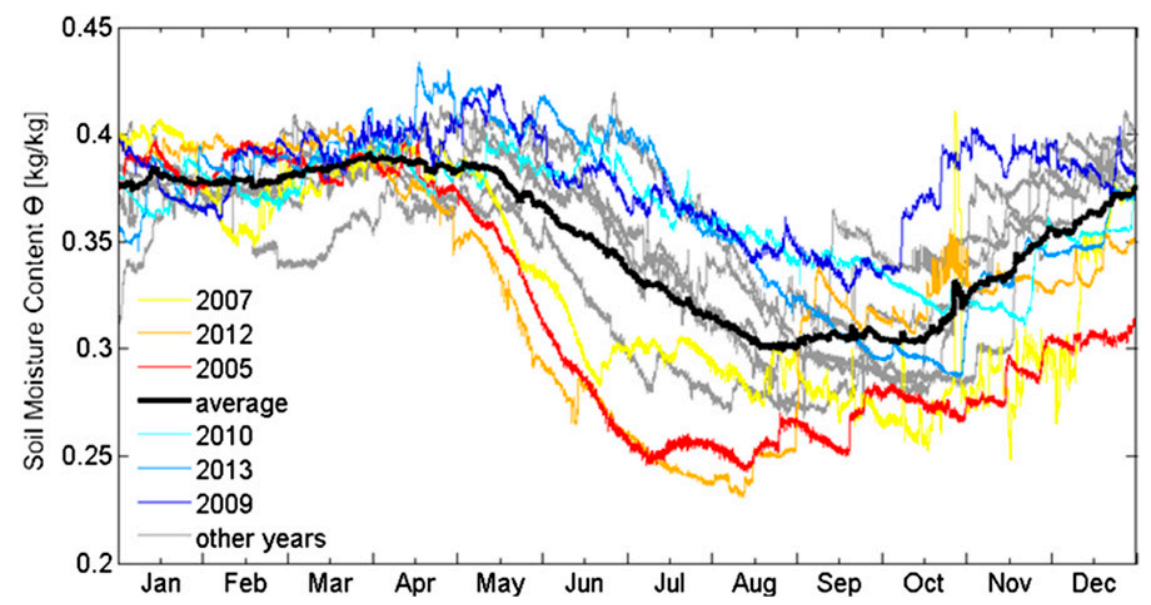

FIG. 3. Statewide average soil moisture content at 50-cm depth for each year during 2003-13. The black line is the 11-yr average. The red, orange, and yellow lines represent years with anomalously dry summers $(2005,2012$, and 2007) and the blue lines indicate the years with anomalously wet summers $(2009,2010$, and 2013).

more noise-reflecting precipitation, while at the deeper depths $(100$ and $150 \mathrm{~cm})$ the soil moisture signal is attenuated as precipitation noise diffuses with soil moisture contents staying above 0.35 (a soil saturation of $70 \%$ ). More information on the soil moisture data can be found in part B of the supplemental material.

\section{Methodology}

The main inputs for the analysis are the statewide precipitation average and the spatially averaged standardized soil moisture datasets for each depth. The cleaning process of these data (e.g., removal of outliers, removal of erroneous data, and uniformizing data) is described in parts $\mathrm{C}$ and $\mathrm{D}$ of the supplemental material. In this study, the method used by Findell and Eltahir (1997) has been extended. To investigate soil moisture-precipitation feedback in Illinois, the analysis has been divided into three parts. In the first part, this study explores whether a significant correlation between soil moisture and subsequent precipitation can be found. In the second part, the possibility of a confounding factor is being investigated. The source areas of precipitation in Illinois during summer by backtracking precipitation are identified. Consequently, the evaporative contributions to precipitation in Illinois, the average precipitable water in the atmosphere, and the zonal and meridional vertically integrated moisture fluxes during summer are calculated. Then, the correlation between precipitation variability and the nearest SSTs and climate indices is investigated. The third part focuses in particular on the late spring/early summer soil moisture-summer precipitation relationship in terms of total precipitation and geographic variability.

\section{a. Soil moisture versus subsequent precipitation}

The correlation between soil moisture and subsequent precipitation is investigated for each hour during spring and summer. First, the statewide precipitation average and the spatially averaged standardized soil moisture for each depth are taken. Subsequently, the soil moisture measurements at a certain hour of the year are selected from each of the 11 years in the dataset. Then, the corresponding subsequent precipitation over a certain period is determined, starting from the hour after the soil moisture observation. Consequently, a simple linear regression model, based on a least squares error fit with soil moisture taken as the independent variable and subsequent precipitation as the dependent variable, is performed (see Fig. 4 for an example). This is repeated for each soil moisture hour during spring and summer, which results in a running linear regression.

For the time scale of the analysis, Findell and Eltahir (1997) used a period of 21 days to represent a short climatic period. Without further explanation, this is rather arbitrary. This study investigates how correlation changes with different time scales. This is done by applying the running simple linear regression to precipitation windows of $1 \mathrm{~h}$ to 4 months with increments of $1 \mathrm{~h}$. This is possible because of the fine resolution of the datasets used in this paper, and it leads to over 12 million regressions being performed. The extended method is applied to each of the six soil moisture depths. Thus, the different aspects that are varied in this analysis are the hour of the year, the precipitation window, and the soil 

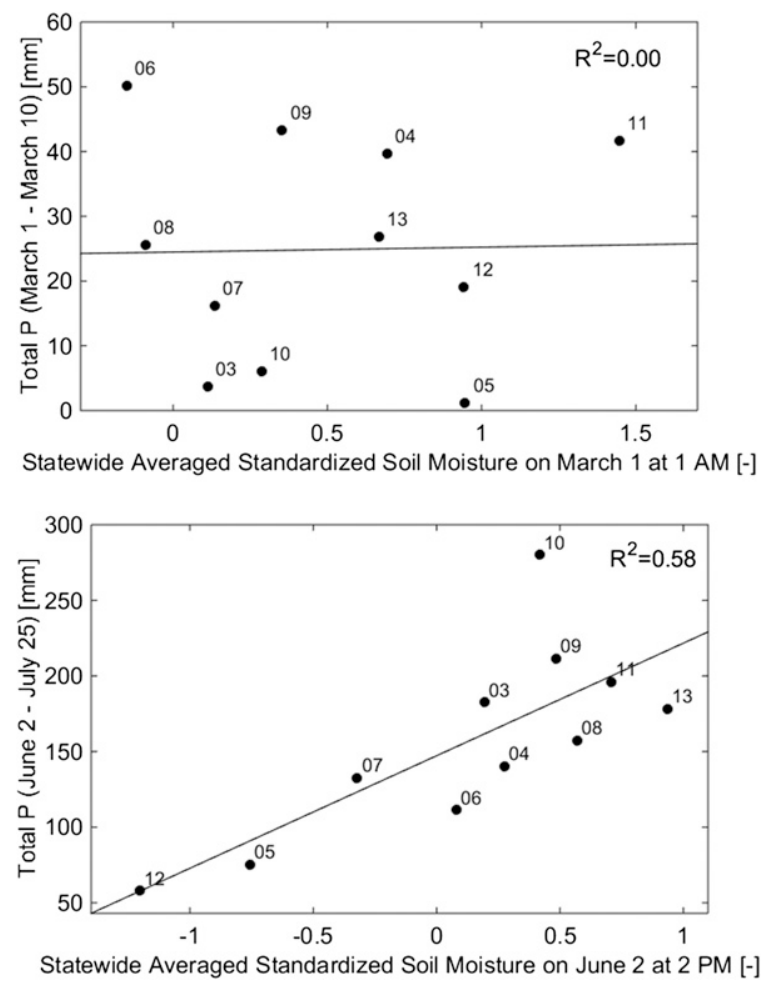

FIG. 4. Examples of a poor and good fit of a simple linear regression between soil moisture and subsequent precipitation. The statewide average soil moisture is based on the standardized soil moisture per station. (top) The statewide average soil moisture measurements at 5-cm depth at 0100 local time (LT) 1 Mar ( $x$ axis) are plotted against the total subsequent precipitation ( $y$ axis) over the next 10 days (1-10 Mar). The numbers beside the dots indicate the year of the bivariate set. The line represents the simple linear regression. The goodness-of-fit indicator $R^{2}$ is zero, so there is no correlation and the variability of soil moisture at $5-\mathrm{cm}$ depth at 0100 LT 1 Mar poorly explains the variability of subsequent precipitation over the next 10 days. (bottom) The statewide average soil moisture measurements at 50-cm depth at 1400 LT 2 Jun and subsequent precipitation over 53 days (from 2 Jun to $25 \mathrm{Jul}$ ). In this case, $R^{2}$ is 0.58 . Thus, soil moisture variability at $50-\mathrm{cm}$ depth at 1400 LT 2 Jun is able to explain $58 \%$ of the precipitation variability over the next 53 days.

moisture depth. The rationale for extending the series up to 4 months is that, particularly at deeper (root zone) soil layers, the soil moisture is a reflection of the climate of the preceding period of weeks to months. The soil moisture anomalies could result in transpiration anomalies, which then possibly influence precipitation over a longer time period as well.

To compare the large amounts of resulting regressions, the coefficient of determination $R^{2}$, a goodness-offit metric, is determined for each regression (see Fig. 4 for an example of a poor and good fit). Calculated as the ratio of residual sum of squares over the total sum of squares, $R^{2}$ represents the variability of subsequent precipitation that can be explained by the variability of soil moisture. The results are smoothed over 21 days and the $5 \%$ and $10 \%$ levels of significance $(0.36$ and 0.27 , respectively) are calculated by means of an $F$ test for the unsmoothed hourly $R^{2}$.

\section{b. Possibility of a confounding factor}

\section{1) SOURCE AREAS OF PRECIPITATION}

An obtained correlation does not necessarily imply that there is a soil moisture-precipitation feedback, since it is possibly caused by a confounding factor, which is defined as a third variable that influences both variables in the correlation considered. To find support for a causal character behind the found correlation, it is investigated whether potential confounding factors can be eliminated. Here, nonlocal effects are considered such as SST and continental soil moisture. Therefore, it is first identified whether the wind direction and thus the source area of precipitation is rather different during wet and dry years. The source areas of precipitation are called precipitationsheds (Keys et al. 2012, 2014). These source areas are identified by tracking the precipitation from Illinois backward in time with the atmospheric moisture tracking model [Water Accounting Model-2 layers (WAM-2layers); van der Ent 2014]. This model is forced by ERA-Interim (Dee et al. 2011) at $1.5^{\circ} \times 1.5^{\circ}$ resolution (see Fig. 1), 6-hourly wind speeds and humidity, and 3-hourly evaporation and precipitation, all of which are uniformly downscaled to $15 \mathrm{~min}$. However, the ERA-Interim precipitation data over Illinois are replaced by the interpolated data from the Illinois Climate Network. For the identified source areas, the evaporative contributions for precipitation in Illinois during summer are calculated to investigate whether there is a difference between wet and dry years. Also, the precipitable water in the atmosphere and the zonal and meridional vertically integrated moisture fluxes are determined, as well as the difference between wet and dry years.

\section{2) Teleconnections BetweEn SSTS AND PRECIPITATION}

A potentially important mechanism for the strong soil moisture-precipitation correlations is the teleconnection between SST and precipitation. In this study, the SSTs in the Gulf of Mexico and the Pacific Ocean as well as a number of other climate indices are correlated with precipitation in Illinois, essentially in the same way as described in section 4a. The SST data used are the 4-km Advanced Very High Resolution Radiometer (AVHRR) Pathfinder, version 5.1, data, obtained from the U.S. National Oceanographic Data Center (NODC/NOAA) 

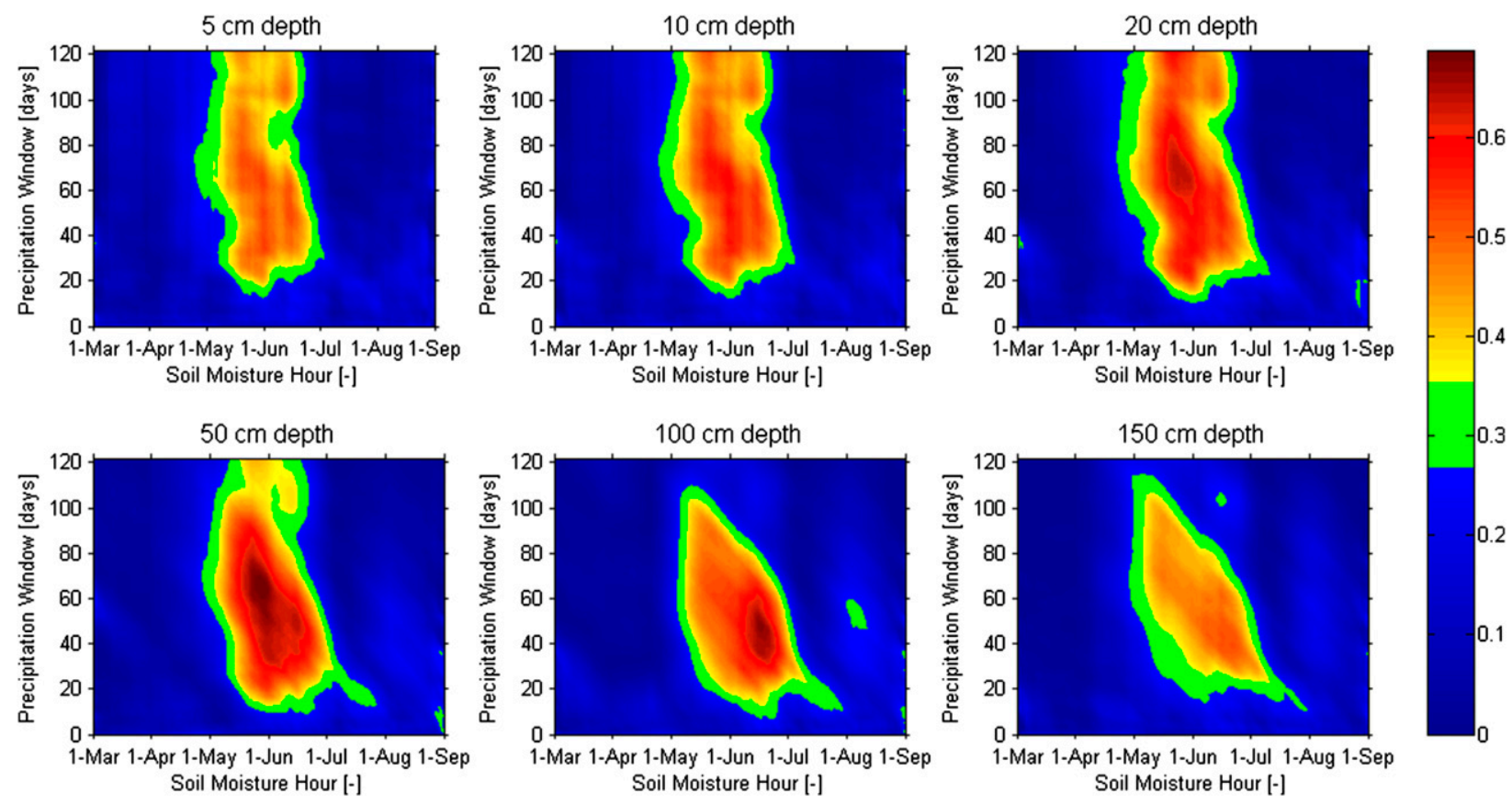

FIG. 5. Running $R^{2}$ between soil moisture hour and precipitation over varying windows (from $1 \mathrm{~h}$ to 4 months) at six depths after 21 -day smoothing over the $x$ axis. The $x$ axis represents the hour of the year considered for the soil moisture set. The $y$ axis indicates the length of the period over which the subsequent total precipitation is considered, starting from the hour after the considered soil moisture hour. The color bar signifies the $R^{2}$ values. The green colors are within the $5 \%-10 \%$ significance band. For example, $R^{2}$ (1300 LT 1 Jun, 50$)$ indicates how much the variability of soil moisture at 1300 LT 1 Jun can explain the variability of precipitation over the next 50 days.

and GHRSST (http://pathfinder.nodc.noaa.gov; Casey et al. 2010). The area-weighted monthly average SST is computed for the sea grid cells: $20^{\circ}-40^{\circ} \mathrm{N}, 130^{\circ}-100^{\circ} \mathrm{W}$ for the North Pacific and $18^{\circ}-31^{\circ} \mathrm{N}, 100^{\circ}-80^{\circ} \mathrm{W}$ for the Gulf of Mexico. Climate indices based on SST and air pressure can be used as indicators for the regional and global weather patterns. The climate indices used in this analysis are the Southern Oscillation index (SOI), Madden-Julian oscillation 6 (MJO6), North Atlantic Oscillation (NAO), east Pacific/North Pacific pattern (EP/NP), Atlantic multidecadal oscillation (AMO), east Atlantic pattern (EA), and Pacific-North American (PNA) pattern and are obtained from Queensland Government (2014) and NOAA (2014a,b).

\section{c. Late spring soil moisture versus summer precipitation}

A practical use of soil moisture data could be when they have a predictive value for summer precipitation. In this paper four climatic regions in Illinois (Fig. 1 and part A of the supplemental material) are considered, and a simple linear regression is applied between a certain hourly soil moisture value and the precipitation amount over the rest of the summer. The summer is taken to end on 31 August. The analysis is performed for all the hours from 1 May to 31 July. Thus, in this case, the window of the precipitation metric is progressively shortened while moving over time. For each region, the degree of precipitation variability explained by the soil moisture conditions in different regions is computed. Subsequently, the same procedures are repeated for the statewide precipitation.

\section{Results and discussion}

\section{a. Soil moisture versus subsequent precipitation}

Figure 5 presents the $R^{2}$ values of the soil moisture versus subsequent precipitation regressions for six different depths of soil moisture measurements smoothed over a 21-day window. The $R^{2}$ value indicates how much precipitation variability can be explained by soil moisture variability. Four features draw attention. The first and most expressed feature is that significant $R^{2}$ levels are reached only during the months May and June for all depths.

Second, $R^{2}$ is only significant when considering precipitation windows longer than 10-20 days. This indicates that soil moisture variability can only explain precipitation variability over periods longer than this period. Hence, soil moisture is a poor predictor for short 
a) Precipitationshed of Illinois in May - July (2003-2013)

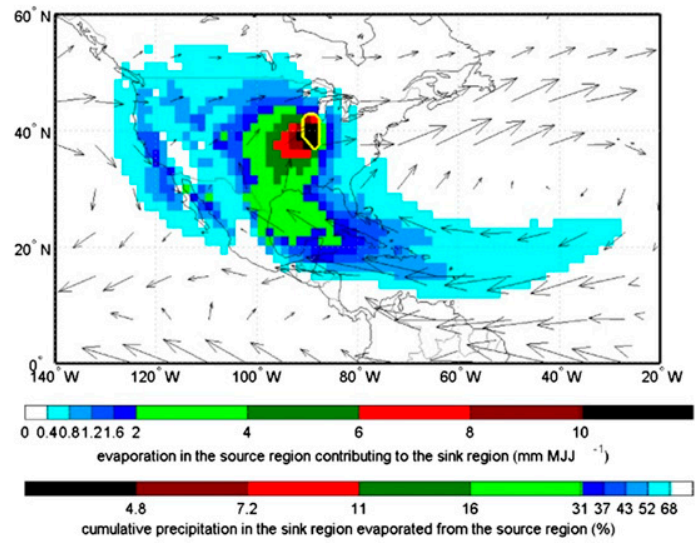

b) Precipitationshed of Illinois in May - July (average wet year)

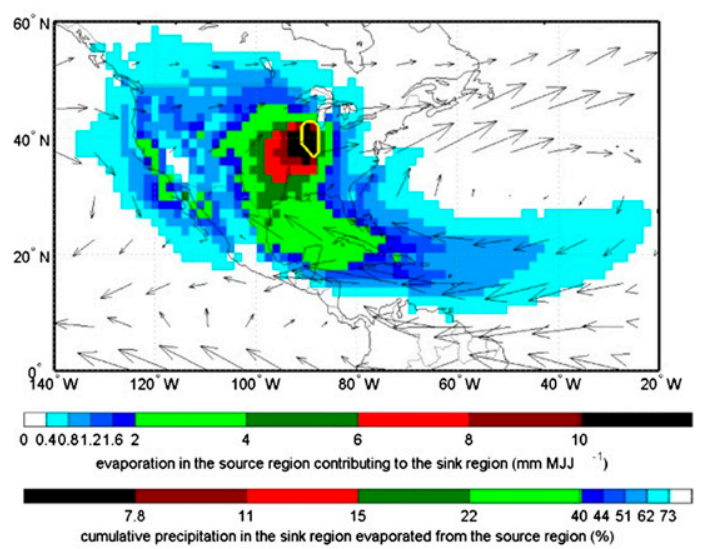

c) Precipitationshed of Illinois in May - July (average dry year)

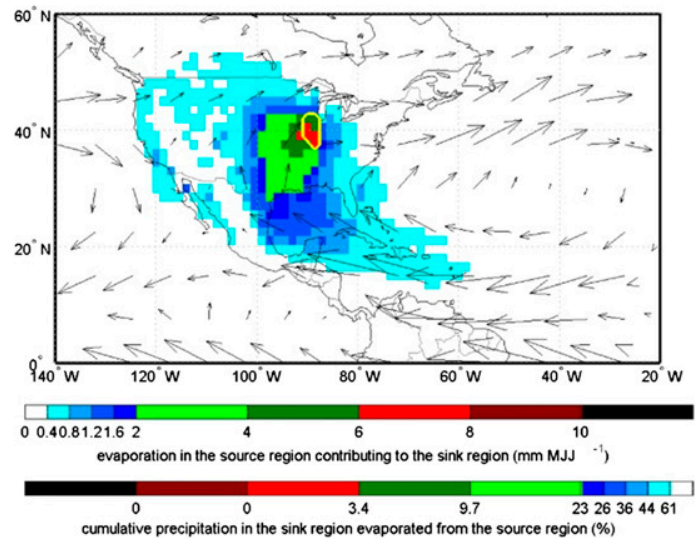

FIG. 6. Precipitationsheds during (a) average MJJ (2003-13), (b) anomalously wet MJJ (2009, 2010, and 2013), and (c) anomalously dry MJJ $(2005,2007$, and 2012). The upper color scale indicates the evaporative contribution each grid cell has to the sink region Illinois (yellow outlined area). The lower color scale indicates the percentage of the precipitation in the yellow outlined area that is cumulatively contributed by the corresponding colors. For example, the light green grid cells in (a) generate $31 \%-16 \%=$ $15 \%$ of the precipitation in the yellow outlined area. The arrows indicate the vertically integrated moisture flux. time scales and single storm events. Instead, it explains climatic periods including several wetting and drying cycles. This may be explained by soil moisture playing only a small indirect role in precipitation generation. For example, soil moisture is probably not the most determining factor on a daily time scale for cloud generation or temperate, and probably not even for evaporation. The soil moisture-precipitation correlation is, therefore, not apparent on the time scale of a few days, but becomes measurable after weeks, when the soil moisture effect can be added to other processes. This may also explain why the previous studies came to contradictory conclusions about soil moistureprecipitation feedback in Illinois. While Salvucci et al. (2002) focused on a very short time scale of 1 day and found no correlation, Findell and Eltahir (1997) considered a time scale of 21 days and found a positive correlation. This paper's results also fit with the results found by Findell et al. (2011), who found Illinois has a weak triggering feedback and amplification feedback strength on a daily time scale (i.e., how evaporative fraction influences convective rainfall).

The third feature is related to the depths. The significance increases with depth until $20-50 \mathrm{~cm}$, where $R^{2}$ reaches almost 0.7 . At deeper depths, where variability goes down and the soil gets more saturated, it dampens again. Higher values of $R^{2}$ at deeper layers are reached later in time, as it requires more time for the deeper soil layers to dry during summer (Fig. 3). This may suggest soil moisture-precipitation feedback to occur through transpiration that draws water from the root zone. Large parts of Illinois are characterized as prairies, and prairie grass and forbs have extensive root systems, with twothirds of their biomass below the surface (Natura 1995). Previous research found that the evaporation zone in Illinois is as deep as $70-100 \mathrm{~cm}$ during summer with the highest probability $(>0.8)$ of upward flux occurrence at $30-50 \mathrm{~cm}$ (Yeh and Famiglietti 2009), which is in line with the findings of Fig. 5.

Fourth, for some depths (most pronounced at 100-cm depth) the duration over which soil moisture explains precipitation variation shortens when progressing through the season. While soil moisture at the beginning of May can explain precipitation variability well over the next 4 months, this reduces to about 1 month by the end of June. Soil moisture variability during May and June can explain more than $40 \%$ of the variability of subsequent rainfall up to the end of August. These significant $R^{2}$ values arise from strong positive correlations (see part E of the supplemental material), which suggest the possibility of a positive local feedback between late spring/early summer soil moisture (May-June) and summer precipitation (through the end of August). 


\section{b. Possibility of a confounding factor}

\section{1) Source AREAS OF PRECIPITATION}

To ascertain whether the positive correlations found in Fig. 5 are attributable to local soil moisture-precipitation coupling or nonlocal effects such as continental soil moisture or synoptic systems, the contributions by source areas of precipitation in Illinois are calculated. Figure 6 presents the different precipitationsheds (i.e., evaporative sources of precipitation) for precipitation during the average and during the wet and dry of periods May-July (MJJ; see also Fig. 3). The arrows indicate the average direction and strength of the vertically integrated moisture flux. It can be observed that the strongest moisture sources (by intensity) for Illinois can be found locally and several hundred kilometers to the west and south of Illinois. The Gulf of Mexico is the strongest oceanic source region (because a large area contributes), but the Pacific Ocean close to the west coast of North America also contributes relatively strongly (see also Table 1 and Fig. 7).

Table 1 shows the evaporative contributions to rainfall in Illinois from the zones indicated in Fig. 7. It can be seen that the absolute differences are large, but the percentagewise contributions to precipitation by the different zones is almost constant. It is interesting to note that, while the absolute contribution of evaporation from the east of the Rocky Mountains is smaller during dry years compared to wet years (Fig. 6c), the relative contribution to precipitation is slightly larger $(35.8 \%$ vs $30.7 \%)$, while relative to local evaporation less ends up as rain in Illinois $(0.4 \%$ vs $0.8 \%$ ). Dry years see lower inflow of moist air from the Gulf of Mexico, but the relative contribution to precipitation is in fact slightly larger during dry years compared to wet years $(22.4 \%$ vs $21.1 \%)$. The regional evaporation recycling in the Illinois region remains constant percentagewise, but fluctuates in absolute terms. It should be noted that these contributions are by no means statistically significant; thus, no hard conclusions should be drawn.

When looking at the MJJ precipitationshed during wet (Fig. 6b) and dry (Fig. 6c) years, it can be observed that the shapes of the contours of evaporation are very similar to the average pattern (Fig. 6a). Figure 8a shows the average precipitable water in the region, and Fig. $8 \mathrm{~b}$ shows the difference in precipitable water between wet and dry years. This figure shows that precipitable water during wet years is greater above the strongest source areas of precipitation in Illinois. Figures $8 \mathrm{c}-\mathrm{f}$ show the zonal and meridional vertically integrated moisture flux during the average and during the wet minus dry periods of MJJ. Figures $8 \mathrm{~d}$ and $8 \mathrm{f}$ seem to indicate that a stronger circulation of atmospheric moisture is present in wet MJJ periods over the Gulf of Mexico from east to west onto the mainland of North America to the north and transported again stronger to the east over Illinois toward the Atlantic. Over the Pacific, the moisture flux remains more constant between wet and dry years.

This analysis indicates that large-scale circulation plays a role in interannual precipitation variability in Illinois, given the increased moisture flow (Figs. 8d,f). However, based on the rather stable precipitationshed (Fig. 6) and the increased precipitable water, there is some supporting evidence for the existence of a seasonal soil moisture-precipitation feedback as well. Moreover, soil moisture can also play an indirect role in the soil moisture-precipitation feedback by local soil moisture contributing to the triggering of precipitation, without being the direct contributor of moisture. However, this direct and indirect feedback is probably acting much more on a (sub)continental-scale rather than it being a purely local feedback mechanism.

\section{2) Nonlocal EFFect: Teleconnections}

To further investigate potential confounding factors, the nonlocal effects of teleconnections are studied. In this section, the results of the influence of large-scale forcing on precipitation through teleconnections are presented. Figure 9 shows the correlations between seven major climate indices, two regional SSTs, and subsequent precipitation in Illinois. The seven climate indices considered are the SOI, MJO6, NAO, EP/NP, AMO, EA, and PNA. The two regional SSTs, Gulf of Mexico (SST-GM) and North Pacific (SST-NP), are in the major source regions of precipitation in Illinois (see Fig. 6). The $R^{2}$ in Fig. 9 indicates how much of the precipitation variability can be explained by teleconnections. Most of the correlations are very low or nonexistent. In section $5 b(1)$, it could be seen that largescale forcing plays a role in terms of interannual changes in moisture contribution, but seasonal precipitation variability is not well explained by SSTs or climate indices.

The North Pacific SST in March and May seems to be able to explain some precipitation variability, but is strangely enough not found in April. The Gulf of Mexico SST can explain some variability of the precipitation in July. Of the climate indices, only the Southern Oscillation at the end of May can slightly explain summer precipitation, with $R^{2}$ values within the $5 \%-10 \%$ level of significance range. Those $R^{2}$ values represent positive correlations (see part E of the supplemental material). This indicates that a more positive SOI (associated 
TABLE 1. Overview of evaporative contribution to precipitation in Illinois from the most important zones (see Fig. 7) for an average MJJ (2003-13), anomalously wet MJJ (2009, 2010, and 2013), and anomalously dry MJJ (2005, 2007, and 2012). Precipitation in Illinois is averaged from station data; evaporation data are spatially averaged ERA-Interim data. The contributions are calculated with WAM2layers.

\begin{tabular}{|c|c|c|c|c|}
\hline & Avg year & Wet year & Dry year & Wet minus dry \\
\hline \multicolumn{5}{|l|}{ Precipitation $\left[\mathrm{mm}(3 \text { months })^{-1}\right]$} \\
\hline Illinois & 268 & 395 & 147 & 248 \\
\hline \multicolumn{5}{|l|}{ Evaporation [mm (3 months $\left.)^{-1}\right]$} \\
\hline Illinois & 375 & 384 & 349 & 35 \\
\hline East of Rocky Mountains & 283 & 285 & 282 & 3 \\
\hline West of Rocky Mountains & 157 & 156 & 153 & 3 \\
\hline Pacific Ocean zone & 210 & 211 & 214 & -3 \\
\hline Gulf of Mexico and Atlantic Ocean zone & 410 & 417 & 407 & 11 \\
\hline \multicolumn{5}{|c|}{ Fraction of evaporation in zone contributing to precipitation in Illinois $(\%)$} \\
\hline Illinois & 3.2 & 4.5 & 1.8 & 2.6 \\
\hline East of Rocky Mountains & 0.6 & 0.8 & 0.4 & 0.5 \\
\hline West of Rocky Mountains & 0.5 & 0.7 & 0.3 & 0.4 \\
\hline Pacific Ocean zone & 0.3 & 0.4 & 0.1 & 0.3 \\
\hline Gulf of Mexico and Atlantic Ocean Zone & 0.2 & 0.3 & 0.1 & 0.2 \\
\hline \multicolumn{5}{|c|}{ Total evaporated moisture contributed to precipitation in Illinois $\left[10^{12} \mathrm{~kg}(3 \text { months })^{-1}\right]$} \\
\hline Illinois (i.e., regional evaporation recycling ratio) & 1.76 & 2.56 & 0.96 & 1.60 \\
\hline East of Rocky Mountains & 12.49 & 18.03 & 7.81 & 10.22 \\
\hline West of Rocky Mountains & 1.76 & 2.49 & 0.90 & 1.59 \\
\hline Pacific Ocean zone & 1.50 & 2.22 & 0.63 & 1.60 \\
\hline Gulf of Mexico and Atlantic Ocean zone & 8.30 & 12.36 & 4.89 & 7.48 \\
\hline Rest & 13.96 & 21.05 & 6.60 & 14.45 \\
\hline \multicolumn{5}{|c|}{ Fraction of precipitation in Illinois contributed by (evaporated from) zone (\%) } \\
\hline Illinois (i.e., regional evaporation recycling ratio) & 4.4 & 4.4 & 4.4 & 0.0 \\
\hline East of Rocky Mountains & 31.4 & 30.7 & 35.8 & -5.1 \\
\hline West of Rocky Mountains & 4.4 & 4.2 & 4.2 & 0.1 \\
\hline Pacific Ocean zone & 3.8 & 3.8 & 2.9 & 0.9 \\
\hline Gulf of Mexico and Atlantic Ocean zone & 20.9 & 21.1 & 22.4 & -1.4 \\
\hline Rest & 35.1 & 35.9 & 30.3 & 5.5 \\
\hline
\end{tabular}

with a low air surface pressure in the western Pacific and stronger trade winds) is associated with more precipitation in Illinois. For spring precipitation, only the EA shows weakly significant $R^{2}$ values (March), representing negative correlations (see part $\mathrm{E}$ of the supplemental material). MJO6 shows a significant correlation in August for long time scales, thus not for precipitation summer, but in October-December. It should be noted that even the significant $R^{2}$ values could be a statistical artifact as with so many data points one would also find some significant values. It is in any case clear that the teleconnections show much weaker correlations with spring/summer precipitation compared to the soil moisture data (see Fig. 5).

\section{c. Late spring soil moisture versus summer precipitation}

\section{1) Statewide Results}

In this section, the late spring/early summer soil moisture influence on precipitation over the rest of the summer is further investigated. Given that soil moisture at $50-\mathrm{cm}$ depth suggests the strongest evidence of this relationship (see Fig. 5), this section focuses here on this depth and using the total precipitation metric. The summer is taken to end on 31 August. Similar tests were ran with the precipitation occurrence metric, but only weak correlations were found.

Figure 10 shows the $R^{2}$ values between soil moisture and the precipitation during the rest of the summer (through 31 August) for each hour running from 1 May

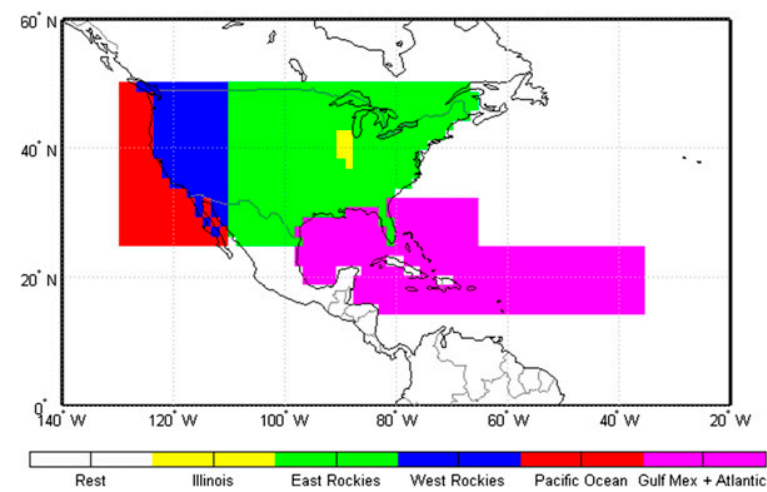

FIG. 7. The most important zones from which evaporation contributes to precipitation in Illinois. 
Precipitable water in MJJ (2003-2013)

a)

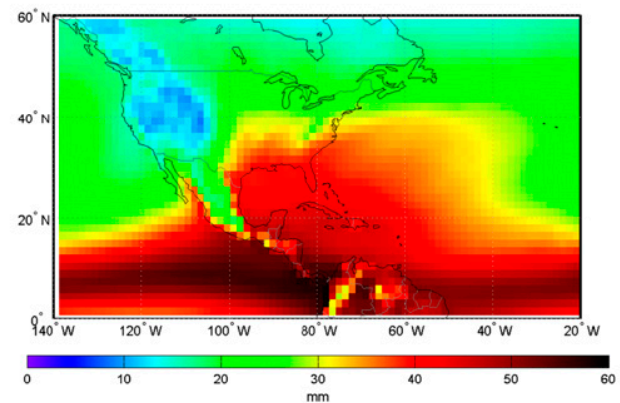

Vertically integrated moisture flux to the east in MJJ (2003-2013)

c)

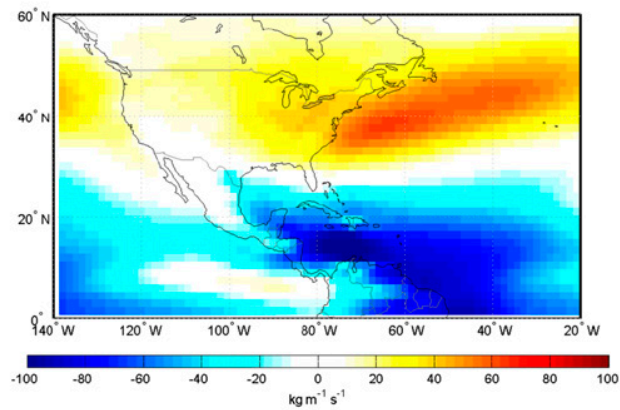

Vertically integrated moisture flux to the north in MJJ (2003-2013)

e)

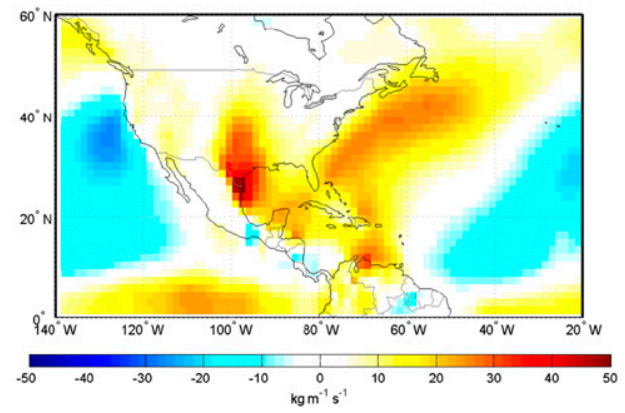

Precipitable water in MJJ (Average wet year - Average dry year)

b)

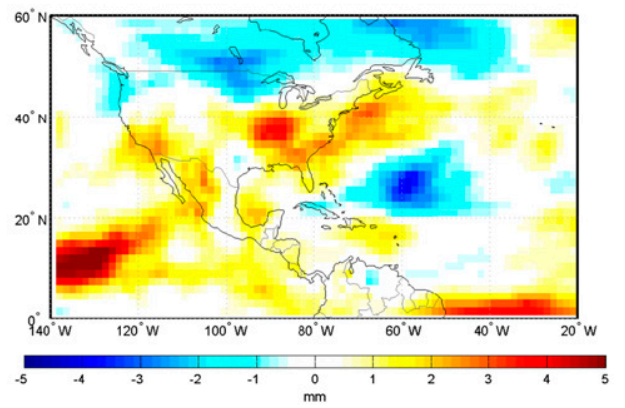

Vertically integrated moisture flux to the east in MJJ

d)

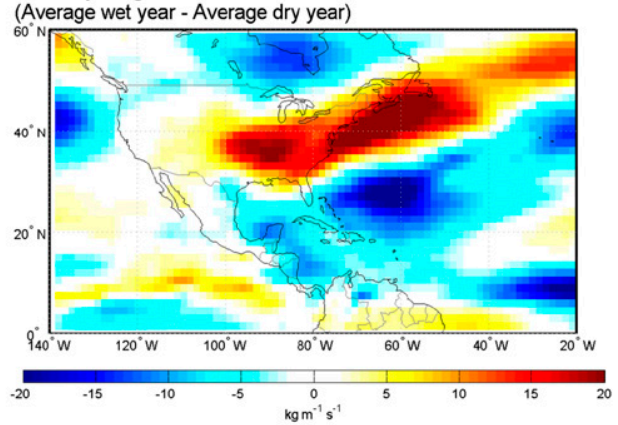

Vertically integrated moisture flux to the north in MJJ

f)

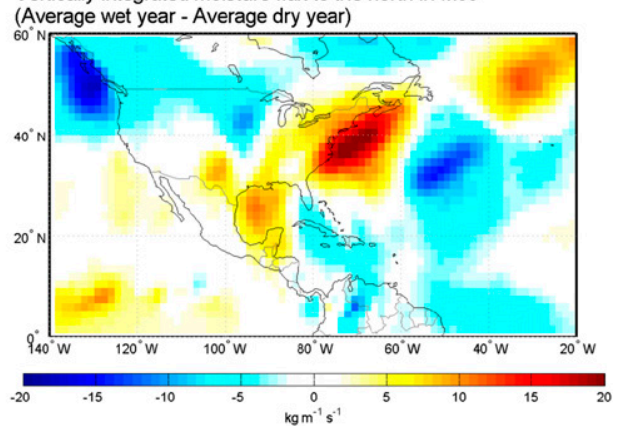

FIG. 8. (a),(b) Average precipitable water in the atmosphere; (c),(d) zonal vertically integrated moisture flux; and (e),(f) meridional vertically integrated moisture flux during MJJ for (left) average MJJ and (right) anomalously wet $\operatorname{MJJ}(2009,2010$, and 2013) minus anomalously dry MJJ (2005, 2007, and 2012).

to 31 July. The $R^{2}$ indicates how well soil moisture variability can explain the total precipitation variability during the rest of the summer. The window over which the total precipitation is considered shortens while moving through time. The $R^{2}$ is significant for much of May and June. The summer precipitation variability is best explained by soil moisture at the end of May where $R^{2}$ reaches a maximum of $67 \%$ on 23 May. This suggests that dry (wet) springs are followed by dry (wet) summers.

\section{2) GEOGRAPHIC VARIABILITY}

In this section the spatial variability across the four climatological zones of Illinois (see Fig. 1), based on the spatial precipitation gradient, of the late spring/early summer soil moisture-summer precipitation correlation is further investigated. The soil moisture and subsequent precipitation of the different climatological zones are cross correlated. Figure 11 presents the resulting $R^{2}$ values per zone (i.e., northwest, northcentral, south-central, and southeast; see Fig. 1). Each panel represents a zone. The $R^{2}$ indicates the amount of summer precipitation variability explained by soil moisture from the northwest (red), north-central (orange), south-central (blue), and southeast (green) regions and statewide (black).

The northwest precipitation (Fig. 11a) is least well explained by soil moisture variability compared to any 

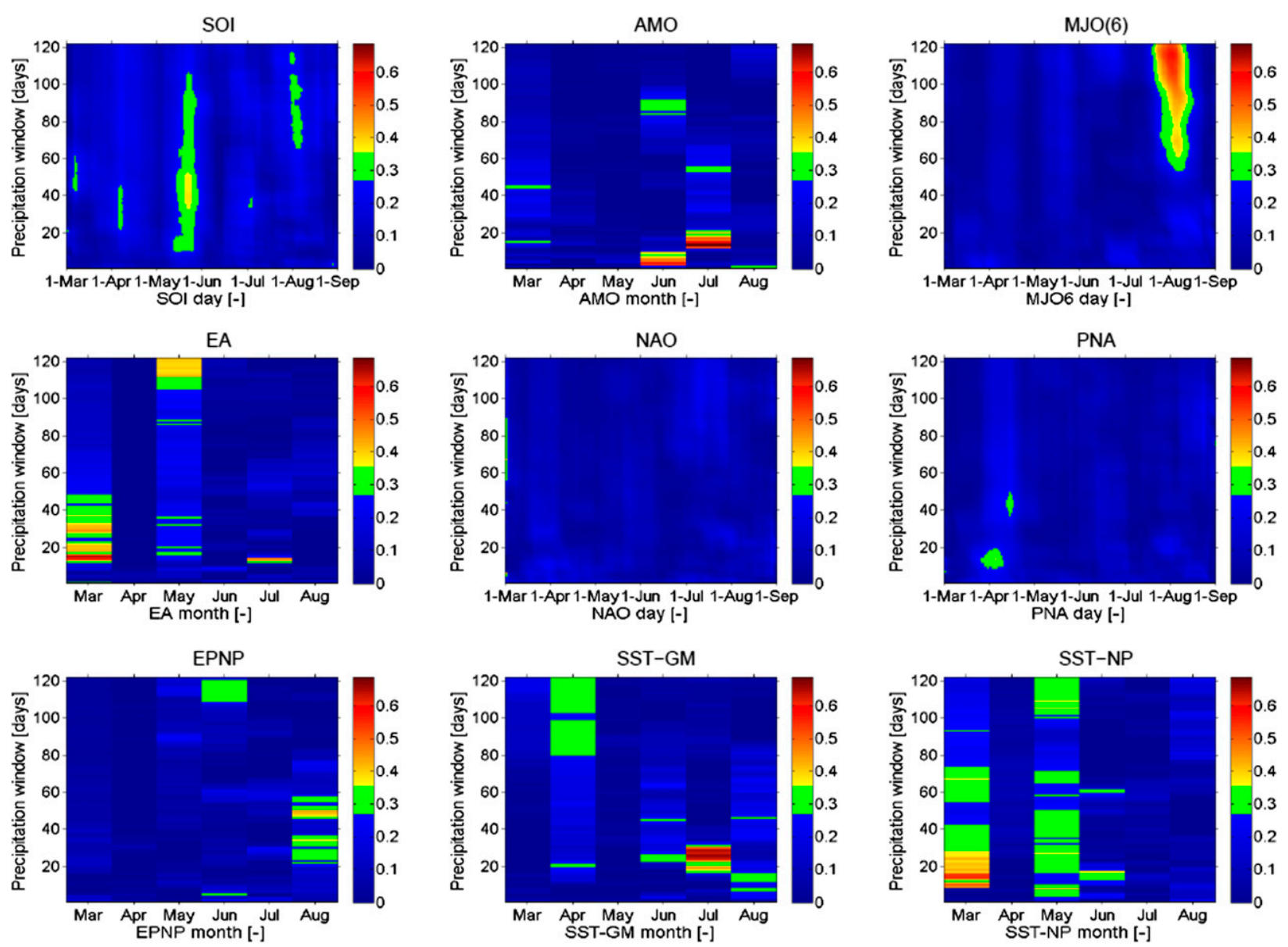

FIG. 9. The $R^{2}$ between climate index day/month and subsequent precipitation over a varying window (from $1 \mathrm{~h}$ to $4 \mathrm{months}$ ). The $x$ axis represents the day/month of the year considered for the climate index set. The $y$ axis indicates the length of the period over which the subsequent total precipitation is considered, starting from the hour after the considered climate index day/month. The regressions at daily resolution have been smoothed over 21 days (i.e., SOI, MJO6, NAO, and PNA). The green colors are the values within the 5\%-10\% significance band. For example, $R^{2}$ ( $\left.1 \mathrm{Jun}, 50\right)$ indicates how much the variability of the climate index on $1 \mathrm{Jun}$ can explain the variability of precipitation over the 50 days after 1 Jun.

of the other regions. The summer precipitation in the north-central region (Fig. 11b) is best explained by the soil moisture in the northwest region in the second half of May. In June, the southeast soil moisture is the best predictor for summer precipitation in the northwest and north-central regions, but $R^{2}$ is not significant. The region in which summer precipitation can be best explained by the soil moisture of the different regions is the south-central (Fig. 11c). For this region, significant $R^{2}$ values are reached from the end of May to mid-June. It is best explained by the soil moisture conditions in the northwest (reaching a maximum $R^{2}$ of about 0.8 in early June), followed by the state and the south-central region itself. Summer precipitation in the southeast region (Fig. 11d) is relatively well explained by soil moisture from each region in spring, but precipitation predictability diminishes during June.
Overall, the soil moisture variability in the northwest region is shown to be the best predictor for summer precipitation in the other regions, while the southeast is a poor predictor. Looking at the precipitationshed (see Fig. 6) of Illinois, it is not likely that there is a direct cause of more soil moisture in the north of Illinois leading to more precipitation in the south. A more plausible explanation may be that this is caused by the soil moisture at $50-\mathrm{cm}$ depth in the drier northwest showing a clearer spread between wet and dry years earlier in the season compared to the soil moisture in the other regions (see part $\mathrm{F}$ of the supplemental material).

These results show that late spring/early summer soil moisture conditions can be used as an indicator for the wetness conditions during the summer. These results, however, also show that the most useful information does not have to be the local information. Moreover, for 


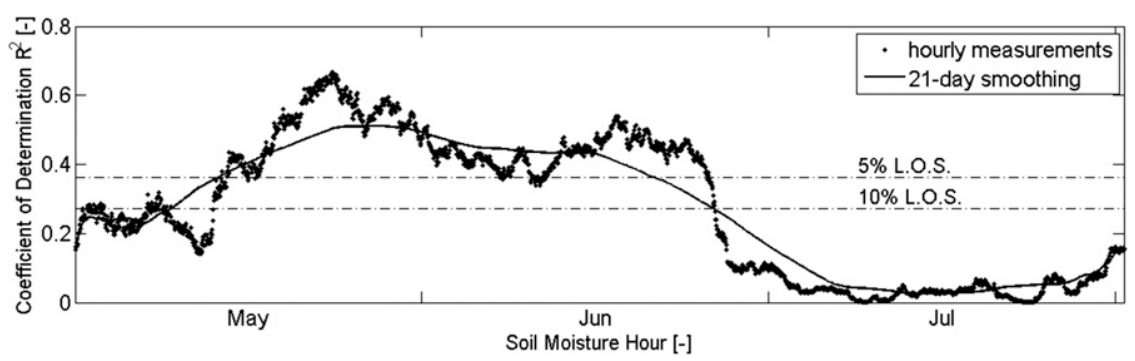

FIG. 10. The $R^{2}$ between soil moisture hour and total precipitation over the rest of the summer (starting from the hour after the considered soil moisture hour to $31 \mathrm{Aug}$ ). For example, the $R^{2}$ value at 1300 LT 1 Jun indicates how much the variability of soil moisture at 1300 LT 1 Jun can explain the variability of precipitation over the rest of the summer, from 1400 LT 1 Jun to 31 Aug, the end of the summer. The solid line represents the smoothed $R^{2}$ values over 21 days. The dotted lines represent the $5 \%$ and $10 \%$ levels of significance (L.O.S.).

each region the period from which the most useful information can be gained differs, making predictions rather complex.

\section{Summary and conclusions}

With newly available hourly soil moisture data (2003$13)$, the previously disputed hypothesis that soil moisture is positively correlated with subsequent precipitation in Illinois was revisited based on observed data. In this paper, it is pointed out that the results from previous studies on soil moisture-precipitation feedback in Illinois are hard to compare as soil moistureprecipitation feedback is studied using different approaches (i.e., method, precipitation metric, and temporal and spatial scales).

Statewide, a strong positive correlation between late spring/early summer soil moisture at the root-zone depth and summer precipitation was found, particularly in terms of total precipitation. This relationship is strongest on the monthly to seasonal time scale, when the soil moisture effect can be added to other processes. On the daily to weekly time scale, however, no relation is found. This indicates that soil moisture plays only a small indirect role in precipitation generation.

To link the found correlations to soil moistureprecipitation feedback this paper has made the distinction between precipitation induced by local soil moisture-precipitation coupling (over Illinois) and precipitation as a result of nonlocal effects, teleconnections and continental soil moisture. This paper provides little evidence for large-scale forcing of seasonal precipitation variability and precipitation persistence in Illinois, given the low correlations between a number of climate indices (SOI, MJO6, NAO, EP/NP, AMO, EA, and PNA) and subsequent precipitation, as well as the low correlation between the SSTs (Gulf of Mexico and Pacific Ocean) and subsequent precipitation.
However, there is a somewhat stronger moisture flow from the Gulf of Mexico onto the continent and subsequently to Illinois during wet years. This increased moisture flow indicates that large-scale circulation plays a role in interannual precipitation variability in Illinois. Yet, from back-trajectory tracking of Illinois precipitation, it was observed that precipitable water during wet years is greater above the strongest sources area of precipitation in Illinois, being locally and several hundred kilometers to the west of Illinois, providing supporting evidence for seasonal soil moistureprecipitation feedback. Together with the long time scale of the soil moisture-precipitation correlation and the weak influence of SSTs and climate indices, this suggests the feedback acting much more on a (sub) continental scale rather than it being a purely local feedback mechanism.

It can be concluded that integrating over a longer temporal and spatial scale, it seems likely that increased soil moisture is responsible for more evaporation, higher atmospheric water content, and more precipitation. Given there are no other major external influences beyond the scope of this paper, the results of this paper support the hypothesis that soil moisture can significantly impact summer precipitation in continental midlatitude regions, as suggested in previous studies (Namias 1952, 1960; Shukla and Mintz 1982; Rind 1982; Yeh et al. 1984; Oglesby and Erickson 1989; Oglesby 1991; Pan et al. 1995; Findell and Eltahir 1997).

Regionally, this paper showed that the late spring/ early summer soil moisture-precipitation correlations vary across Illinois. Precipitation in the northwest and southeast can be poorly predicted by soil moisture over Illinois. This might be due to these regions being susceptible to the local effects, such as Lake Michigan in the north and the hills in the south. On the other hand, precipitation variability over central Illinois can be explained by soil moisture variability in the northwest. 
a)

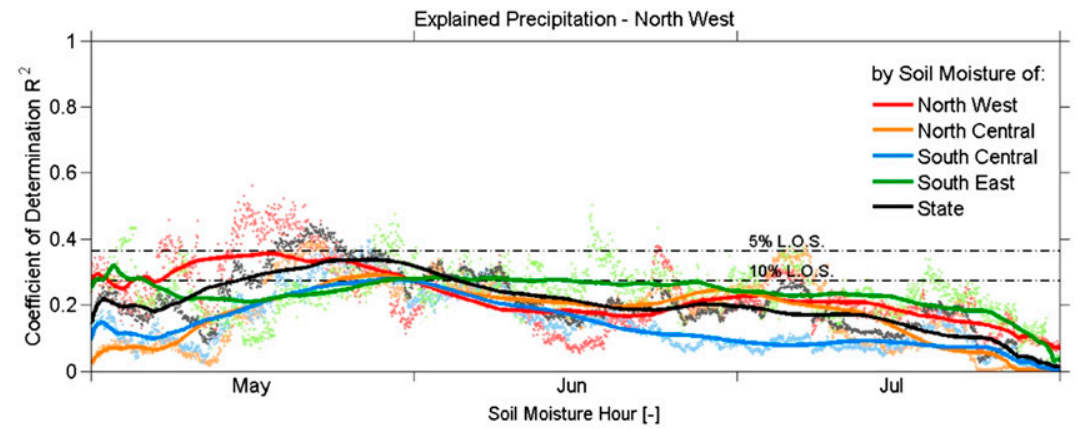

b)

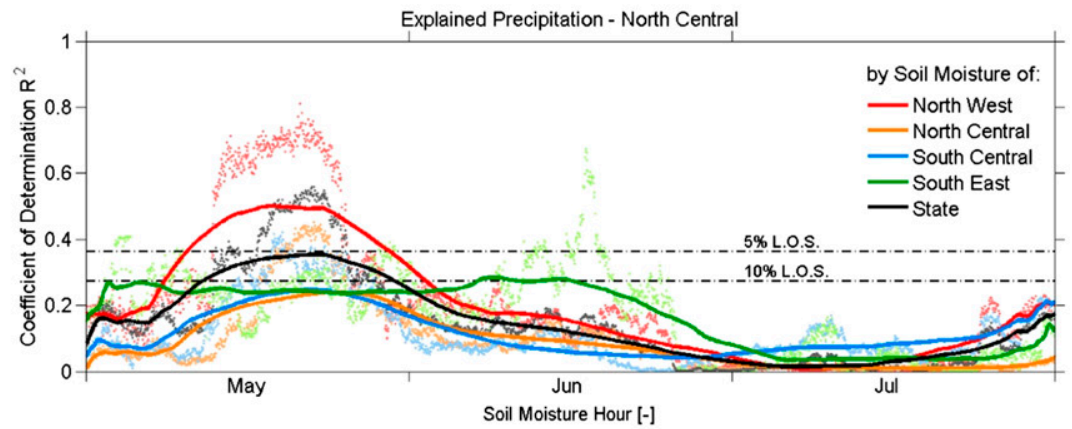

c)

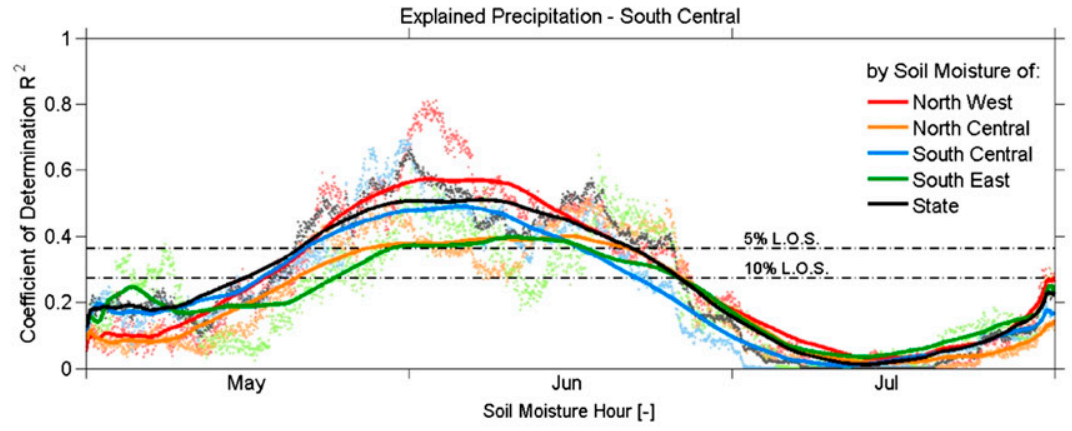

d)

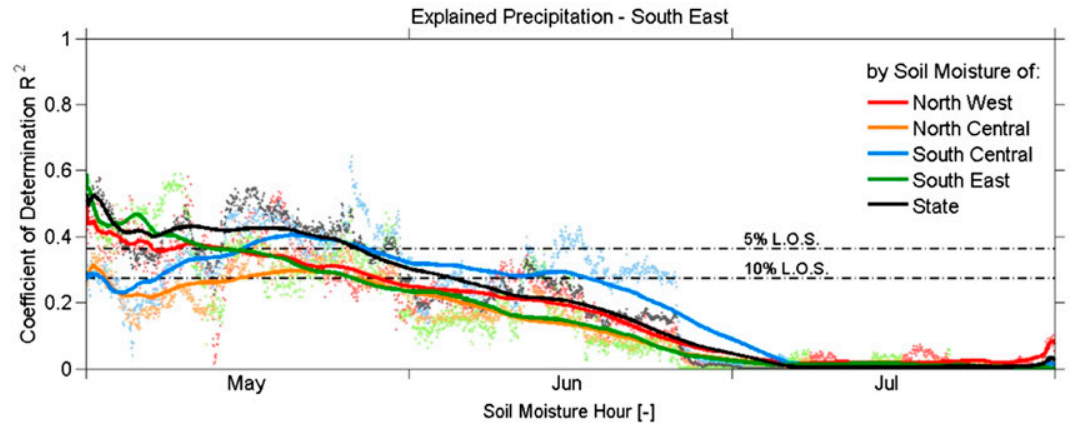

FIG. 11. The summer precipitation variance per region explained by the soil moisture per region. Each graph indicates how much of the summer precipitation of a particular region is explained by the soil moisture during MJJ of the different regions. The dots are the hourly calculated $R^{2}$ and the lines represent the smoothed $R^{2}$ over 21 days. Each dot is based on a simple linear regression between soil moisture at a particular hour and precipitation during the rest of the summer. For example, in (a) the $R^{2}$ value at 1300 LT 1 Jun indicates how well the variability of soil moisture over the northwest (red), north-central (orange), south-central (blue), southeast (green), and statewide (black) locations at 1300 LT 1 Jun can explain the variability of precipitation during the rest of the summer, over the northwest from 1400 LT 1 Jun to 31 Aug. The dotted lines represent the 5\% and 10\% levels of significance (L.O.S.). 
During the second half of May and early June, $R^{2}$ reaches 0.81 for precipitation in north-central and southcentral Illinois, respectively.

Finally, given the scientific and practical relevance of observed soil moisture data, as demonstrated in this paper, the authors want to draw attention to the need for soil moisture measurement networks. Longer time series will produce more robust results. The integrative nature of soil moisture with a seasonal memory is a major control for evaporation, air temperature, and thereby precipitation. Current satellite sensors, on the other hand, only sense the moisture content of the top soil, or even just the vegetation (Steele-Dunne et al. 2012). More monitoring networks can improve the understanding of the poorly understood land surface interactions, which is valuable for climate studies.

Acknowledgments. This work was achieved with the contribution of soil moisture and precipitation data from the Illinois State Water Survey, for which the authors are very thankful. We also thank Dr. Kirsten Findell and the anonymous reviewers for their valuable comments that helped improve this manuscript.

\section{REFERENCES}

Angel, J., 1999: Climate of Illinois narrative. Illinois State Water Survey Doc., 5 pp. [Available online at http://www.isws.illinois. edu/atmos/statecli/General/Illinois-climate-narrative.pdf.]

- 2009: State climatologist office for Illinois. Illinois State Water Survey, accessed 1 May 2014. [Available online at http://www.isws.illinois.edu/atmos/statecli/index.htm.]

Beljaars, A. C. M., P. Viterbo, M. J. Miller, and A. K. Betts, 1996: The anomalous rainfall over the United States during July 1993: Sensitivity to land surface parameterization and soil moisture anomalies. Mon. Wea. Rev., 124, 362-383, doi:10.1175/1520-0493(1996)124<0362:TAROTU>2.0.CO;2.

Bosilovich, M. G., and W. Y. Sun, 1999: Numerical simulation of the 1993 midwestern flood: Land-atmosphere interactions. J. Climate, 12, 1490-1505, doi:10.1175/1520-0442(1999)012<1490: NSOTMF $>2.0 . \mathrm{CO} ; 2$.

Casey, K. S., T. B. Brandon, P. Cornillon, and R. Evans, 2010: The past, present, and future of the AVHRR Pathfinder SST Program. Oceanography from Space: Revisited, V. Barale, J. F. R. Gower, and L. Alberotanza, Eds., Springer, 273-287, doi:10.1007/978-90-481-8681-5_16.

Dee, D. P., and Coauthors, 2011: The ERA-Interim reanalysis: Configuration and performance of the data assimilation system. Quart. J. Roy. Meteor. Soc., 137, 553-597, doi:10.1002/ qj. 828 .

Dirmeyer, P. A., R. D. Koster, and Z. Guo, 2006: Do global models properly represent the feedback between land and atmosphere? J. Hydrometeor., 7, 1177-1198, doi:10.1175/ JHM532.1.

Ek, M. B., and A. A. M. Holtslag, 2004: Influence of soil moisture on boundary layer cloud development. J. Hydrometeor., 5, 86-99, doi:10.1175/1525-7541(2004)005<0086:IOSMOB $>2.0$. $\mathrm{CO} ; 2$.
Findell, K. L., and E. A. B. Eltahir, 1997: An analysis of the soil moisture-rainfall feedback, based on direct observations from Illinois. Water Resour. Res., 33, 725-735, doi:10.1029/ 96WR03756.

$\longrightarrow$, and - , 2003a: Atmospheric controls on soil moistureboundary layer interactions. Part I: Framework development. J. Hydrometeor., 4, 552-569, doi:10.1175/1525-7541(2003)004<0552: ACOSML $>2.0 . \mathrm{CO} ; 2$.

$\longrightarrow$, and - , 2003b: Atmospheric controls on soil moistureboundary layer interactions. Part II: Feedbacks within the continental United States. J. Hydrometeor., 4, 570-583, doi:10.1175/1525-7541(2003)004<0570:ACOSML>2.0.CO;2.

_ P. Gentine, B. R. Lintner, and C. Kerr, 2011: Probability of afternoon precipitation in eastern United States and Mexico enhanced by high evaporation. Nat. Geosci., 4, 434-439, doi:10.1038/ngeo1174.

,,--- , and B. P. Guillod, 2015: Data length requirements for observational estimates of land-atmosphere coupling strength. J. Hydrometeor., 16, 1615-1635, doi:10.1175/ JHM-D-14-0131.1.

Free World Maps, 2014: Download free US maps. Accessed 3 March 2014. [Available online at http://www.freeworldmaps. net/download/united-states.html.]

Guillod, B. P., and Coauthors, 2014: Land-surface controls on afternoon precipitation diagnosed from observational data: Uncertainties and confounding factors. Atmos. Chem. Phys., 14, 8343-8367, doi:10.5194/acp-14-8343-2014.

Hohenegger, C., P. Brockhaus, C. S. Bretherton, and C. Schär, 2009: The soil moisture-precipitation feedback in simulations with explicit and parameterized convection. J. Climate, 22, 5003-5020, doi:10.1175/2009JCLI2604.1.

Illinois Department of Natural Resources, 2013: The drought of 2012: A report of the governor's drought response task force. Illinois DNR Rep., 96 pp. [Available online at https://www. dnr.illinois.gov/WaterResources/Documents/TheDroughtOf2012. pdf.]

Illinois State Water Survey, 2014: Illinois Climate Network: Soil data. ISWS/PRI/WARM, Illinois map, accessed 3 March 2014. [Available online at http://www.isws.illinois.edu/ warm/soil.]

Keys, P. W., R. J. van der Ent, L. J. Gordon, H. Hoff, R. Nikoli, and H. H. G. Savenije, 2012: Analyzing precipitationsheds to understand the vulnerability of rainfall dependent regions. Biogeosciences, 9, 733-746, doi:10.5194/bg-9-733-2012.

, E. A. Barnes, R. J. van der Ent, and L. J. Gordon, 2014: Variability of moisture recycling using a precipitationshed framework. Hydrol. Earth Syst. Sci., 18, 3937-3950, doi:10.5194/hess-18-3937-2014.

Konings, A. G., G. G. Katul, and A. Porporato, 2010: The rainfallno rainfall transition in a coupled land-convective atmosphere system. Geophys. Res. Lett., 37, L14401, doi:10.1029/ 2010GL043967.

Koster, R. D., and Coauthors, 2004: Regions of strong coupling between soil moisture and precipitation. Science, 305, 11381140, doi:10.1126/science.1100217.

_ , and Coauthors, 2011: The second phase of the Global LandAtmosphere Coupling Experiment: Soil moisture contributions to subseasonal forecast skill. J. Hydrometeor., 12, 805-822, doi:10.1175/2011JHM1365.1.

Kunkel, K. E., and Coauthors, 2006: The 2005 Illinois Drought. Informational/Educational Material 2006-03, Illinois State Water Survey, 96 pp. [Available online at http://www.isws. illinois.edu/pubdoc/IEM/ISWSIEM2006-03.pdf.] 
Namias, J., 1952: The annual course of month-to-month persistence in climatic anomalies. Bull. Amer. Meteor. Soc., 33, 279-285.

- 1960: Factors in the initiation, perpetuation and termination of drought. IAHS Publ., 51, 81-94. [Available online at http:// iahs.info/uploads/dms/051010.pdf.]

_ 1991: Spring and summer 1988 drought over the contiguous United States-Causes and prediction. J. Climate, 4, 54-65, doi:10.1175/1520-0442(1991)004<0054:SASDOT>2.0.CO;2.

Natura, H., 1995: Root systems of prairie plants. Conservation Research Institute, 1 p.

NOAA, 2014a: Climate indices: Monthly atmospheric and ocean time series. NOAA/ESRL/PSD, subset used: Daily AMO unsmoothed, accessed 10 June 2014. [Available online at http://www.esrl.noaa.gov/psd/data/climateindices/list.]

- 2014b: Monitoring and data. NOAA/NWS/CPC, subset used: Daily MJO (index 6), monthly EA, daily NAO, daily PNA, and monthly EP-NP, accessed 10 June 2014. [Available online at http://www.cpc.noaa.gov/products/precip/CWlink/daily_mjo_ index/mjo_index.]

Oglesby, R. J., 1991: Springtime soil moisture, natural climatic variability, and North American drought as simulated by the NCAR community climate model 1 . J. Climate, 4, 890-897, doi:10.1175/1520-0442(1991)004<0890:SSMNCV>2.0.CO;2.

— of North American drought. J. Climate, 2, 1362-1380, doi:10.1175/1520-0442(1989)002<1362:SMATPO >2.0.CO;2.

Pal, J. S., and E. A. B. Eltahir, 2001: Pathways relating soil moisture conditions to future summer rainfall within a model of the land-atmosphere system. J. Climate, 14, 1227-1242, doi:10.1175/1520-0442(2001)014<1227:PRSMCT>2.0.CO;2.

$\longrightarrow$, and - 2002: Teleconnections of soil moisture and rainfall during the 1993 Midwest summer flood. Geophys. Res. Lett., 29, 10-13, doi:10.1029/2002GL014815.

Pan, Z., M. Segal, R. Turner, and E. Takle, 1995: Model simulation of impacts of transient surface wetness on summer rainfall in the United States Midwest during drought and flood years. Mon. Wea. Rev., 123, 1575-1581, doi:10.1175/ 1520-0493(1995)123<1575:MSOIOT>2.0.CO;2.

Queensland Government, 2014: SOI data files. Subset used: Daily SOI 19331992 base, accessed 10 June 2014. [Available online at http://www.longpaddock.qld.gov.au/seasonalclimateoutlook/ southernoscillationindex/soidatafiles/index.php.]

Rind, D., 1982: The influence of ground moisture conditions in North America on summer climate as modelled in the GISS GCM. Mon. Wea. Rev., 110, 1487-1494, doi:10.1175/ 1520-0493(1982)110<1487:TIOGMC > 2.0.CO;2.

Rowell, D. L., 1995: Soil Science: Methods and Applications. Routledge, $360 \mathrm{pp}$.

Salvucci, G. D., J. A. Saleem, and R. Kaufmann, 2002: Investigating soil moisture feedbacks on precipitation with tests of Granger causality. Adv. Water Resour., 25, 1305-1312, doi:10.1016/ S0309-1708(02)00057-X.

Santanello, J. A., M. A. Friedl, and W. P. Kustas, 2005: Empirical investigation of convective planetary boundary layer evolution and its relationship with land surface properties and processes. J. Appl. Meteor., 44, 917-932, doi:10.1175/JAM2240.1.

Seneviratne, S. I., T. Corti, E. L. Davin, M. Hirschi, E. B. Jaeger, I. Lehner, B. Orlowsky, and A. J. Teuling, 2010: Investigating soil moisture-climate interactions in a changing climate: A review. Earth Sci. Rev., 99, 125-161, doi:10.1016/j.earscirev.2010.02.004.

Seth, A., and F. Giorgi, 1998: The effects of domain choice on summer precipitation simulation and sensitivity in a regional climate model. J. Climate, 11, 2698-2712, doi:10.1175/ 1520-0442(1998)011<2698:TEODCO > 2.0.CO;2.

Shukla, J., and Y. Mintz, 1982: Influence of land-surface evapotranspiration on the earth's climate. Science, 215, 1498-1501, doi:10.1126/science.215.4539.1498.

Siqueira, M., G. Katul, and A. Porporato, 2009: Soil moisture feedbacks on convection triggers: The role of soil-plant hydrodynamics. J. Hydrometeor., 10, 96-112, doi:10.1175/ 2008JHM1027.1.

Steele-Dunne, S. C., J. Friesen, and N. van de Giesen, 2012: Using diurnal variation in backscatter to detect vegetation water stress. Geosci. Remote Sens., 50, 2618-2629, doi:10.1109/ TGRS.2012.2194156.

Stéfanon, M., P. Drobinski, F. D’Andrea, C. Lebeaupin-Brossier, and S. Bastin, 2014: Soil moisture-temperature feedbacks at meso-scale during summer heat waves over western Europe. Climate Dyn., 42, 1309-1324, doi:10.1007/s00382-013-1794-9.

Taylor, C. M., A. Gounou, F. Guichard, P. P. Harris, R. J. Ellis, F. Couvreux, and M. De Kauwe, 2011: Frequency of Sahelian storm initiation enhanced over mesoscale soil-moisture patterns. Nat. Geosci., 4, 430-433, doi:10.1038/ngeo1173.

- D. Jeu, A. M. Richard, F. Guichard, P. P. Harris, and W. A. Dorigo, 2012: Afternoon rain more likely over drier soils. Nature, 489, 423-426, doi:10.1038/nature11377.

van der Ent, R. J., 2014: A new view on the hydrological cycle over continents. Ph.D. thesis, Delft University of Technology, 106 pp., doi: 10.4233/uuid:0ab824ee-6956-4cc3-b530-3245ab4f32be.

_ , L. Wang-Erlandsson, P. W. Keys, and H. H. G. Savenije, 2014: Contrasting roles of interception and transpiration in the hydrological cycle-Part 2: Moisture recycling. Earth Syst. Dyn., 5, 471-489, doi:10.5194/esd-5-471-2014.

Van Heerwaarden, C. C., J. Vilà-Guerau de Arellano, A. F. Moene, and A. A. M. Holtslag, 2009: Interactions between dry-air entrainment, surface evaporation and convective boundary-layer development. Quart. J. Roy. Meteor. Soc., 135, 1277-1291, doi:10.1002/qj.431.

Wang-Erlandsson, L., R. J. van der Ent, L. J. Gordon, and H. H. G. Savenije, 2014: Contrasting roles of interception and transpiration in the hydrological cycle-Part 1: Simple terrestrial evaporation to atmosphere model. Earth Syst. Dyn., 5, 441469, doi:10.5194/esd-5-441-2014.

Water and Atmospheric Resources Monitoring Program, 2011: Soil moisture and precipitation data. Illinois Climate Network, accessed 3 February 2014. [Available from Illinois State Water Survey, 2204 Griffith Drive, Champaign, IL 61820-7495.]

Wendland, W. M., 1981: Illinois Windpower Program. SWS Contract Rep. 266, 22 pp. [Available online at http://www.isws. illinois.edu/pubdoc/cr/iswscr-266.pdf.]

Yeh, P. J.-F., and J. S. Famiglietti, 2009: Regional groundwater evapotranspiration in Illinois. J. Hydrometeor., 10, 464-478, doi:10.1175/2008JHM1018.1.

Yeh, T.-C., R. T. Wetherald, and S. Manabe, 1984: The effect of soil moisture on the short-term climate and hydrology change-A numerical experiment. Mon. Wea. Rev., 112, 474-490, doi:10.1175/1520-0493(1984)112<0474:TEOSMO>2.0.CO;2. 